\title{
Oxidative stress risk analysis for exposure to diesel exhaust particle-induced reactive oxygen species
}

\author{
Chia-Pin Chio, Szu-Chieh Chen, Kuo-Chih Chiang, Wei-Chun Chou, Chung-Min Liao* \\ Department of Bioenvironmental Systems Engineering, National Taiwan University, \\ Taipei 10617, Taiwan, ROC
}

Received 17 April 2007; received in revised form 10 July 2007; accepted 19 July 2007

Available online 28 August 2007

\begin{abstract}
We constructed a probabilistic risk-based framework to assess the human oxidative stress (OS) risk from diesel exhaust particle (DEP)-induced reactive oxygen species. A human respiratory tract model was used to estimate DEP concentration and cumulative doses in lung regions for three occupational groupings (driver, homeworker and student) in northern, central, and southern Taiwan. Dose-response profiles were reconstructed in terms of the specific ratio of the reduced and oxidized forms of glutathione (GSH/ GSSG ratio) for the human macrophage cell (THP-1) and human bronchial epithelial cell (BEAS-2B). The highest estimated median daily cumulative dose of DEP with $95 \%$ CI was for driver in northern Taiwan $\left(\mathrm{DEP}_{2.5}: 0.716(0.443-1.197) \mathrm{mg}\right.$ and $\left.\mathrm{DEP}_{0.18}: 0.584(0.417-0.822) \mathrm{mg}\right)$, significantly higher than that of the other settings. The driver in northern Taiwan setting had the highest cumulative dose-response calculated over a 2-year exposure period: $0.57(0.41-0.76)$ and $0.70(0.53-0.87)$ for $\mathrm{DEP}_{2.5}$ and $0.40(0.25-0.70)$ and $0.47(0.34-0.80)$ for $\mathrm{DEP}_{0.18}$, respectively, in THP-1 and BEAS-2B cells. Our results implicate that potential risks of OS from above-critical exposure to $\mathrm{DEP}_{2.5}$ in all settings are found, whereas from $\mathrm{DEP}_{0.18}$ in the driver in northern Taiwan setting is also alarming.
\end{abstract}

(C) 2007 Elsevier B.V. All rights reserved.

Keywords: Diesel exhaust particle; Reactive oxygen species; Oxidative stress; Human respiratory tract; Probabilistic risk assessment

\section{Introduction}

Epidemiological studies show a strong correlation between ambient particulate matter (PM) concentrations and adverse health (Donaldson et al., 1998; Cho et al., 2005; Nel, 2005; Reliene et al., 2005; Chen et al., 2006; Tovalin et al., 2006). Chio et al. (2004) identified that the vehicle emissions as the largest source of airborne PM in

\footnotetext{
* Corresponding author. Tel.: +88622363 4512; fax: +88622362 6433.

E-mail address: cmliao@ntu.edu.tw (C.-M. Liao).
}

Taiwan, and evidence also shows that diesel vehicle emissions contribute more to the ambient PM load than gasoline vehicle emissions (Gertler, 2005). Furthermore, diesel vehicle emissions are the major source of ultrafine particulate matter (PM of diameter $<0.1 \mu \mathrm{m}$ ) (Lin et al., 2005), which is more readily respirable than larger diameter particulate. Knaapen et al. (2004) found that inhalation of diesel exhaust particle (DEP) can induce epithelial cells in the lung to generate cell-damaging intracellular reactive oxygen species (ROS), and the USEPA (2002) has listed DEP as an atmospheric toxin due to the cancer and other disease effects associated with whole diesel exhaust exposure. 


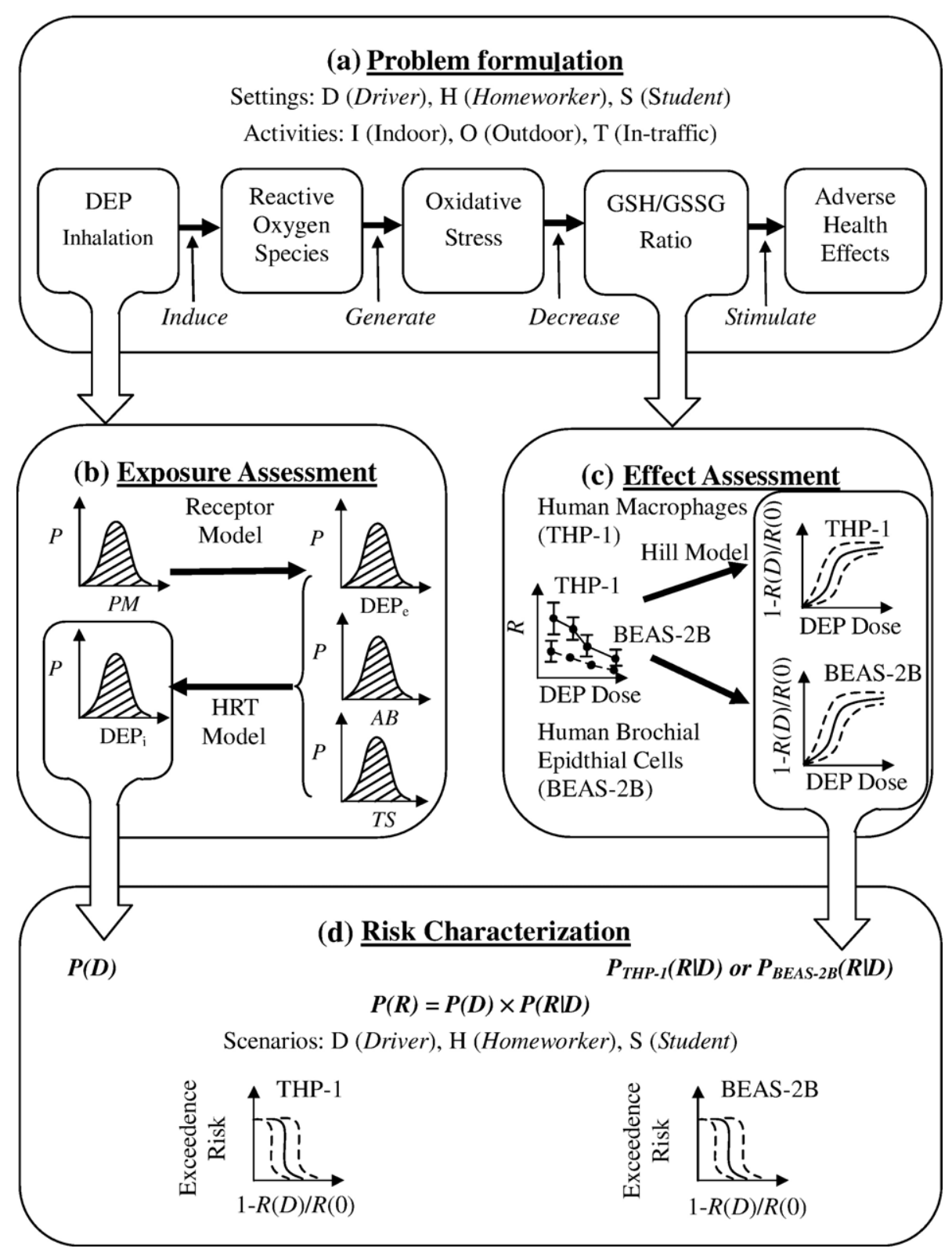

Fig. 1. Schematic diagram showing the proposed probabilistic assessment framework for oxidative stress risk for human exposed to diesel exhaust particle-induced reactive oxygen species.

ROS are broadly defined as oxygen-containing chemical species with reactive chemical properties, and include free radicals, superoxide $\left(\mathrm{O}_{2} \bullet^{-}\right)$, and hydroxyl radicals (HO•) (Pelicano et al., 2004). Hung and Wang (2001) measured $\mathrm{H}_{2} \mathrm{O}_{2}$ concentration as a surrogate for ROS concentration in Taipei and found it ranged from 0.016 to 0.146 and 0.026 to $0.592 \mathrm{nM} \mathrm{m}^{-3}$ in fine $\left(\mathrm{PM}_{2.5}, \mathrm{PM}\right.$ of diameter $\left.<2.5 \mu \mathrm{m}\right)$ and ultrafine $\mathrm{PM}$, respectively. Kao and Wang (2002) also indicated that the mean ROS concentrations in $\mathrm{PM}_{1}$ (PM of diameter
$<1.0 \mu \mathrm{m})$ and $\mathrm{PM}_{2.5}$ from incense smoke were $15.6 \pm 1.0$ and $13.5 \pm 1.3 \mathrm{nmol} \mathrm{H}_{2} \mathrm{O}_{2} \mathrm{mg}^{-1}$ of particle, respectively. ROS are also constantly generated in the cell via a variety of pathways, including enzyme-catalyzed and nonenzyme-catalyzed reactions (Pelicano et al., 2004), and can damage cellular proteins, lipid, membranes, and DNA (Iwai et al., 2000; Nel, 2005; Reliene et al., 2005; Tovalin et al., 2006). Ordinarily ROS are cleared from the cell by the action of antioxidants such as glutathione (GSH). However, Nel (2005) reported that the generation 
Table 1

Published data for $\mathrm{PM}_{2.5}$ and $\mathrm{PM}_{0.18}$ in Taiwan

\begin{tabular}{|c|c|c|c|c|}
\hline Activity/regions & $\begin{array}{l}\text { Measured } \\
\mathrm{PM}_{0.18} \\
\left(\mu \mathrm{g} \mathrm{m}^{-3}\right)\end{array}$ & $\begin{array}{l}\text { Estimated } \\
\mathrm{PM}_{0.18} \\
\left(\mu \mathrm{g} \mathrm{m}^{-3}\right)^{\mathrm{a}}\end{array}$ & $\begin{array}{l}\text { Measured } \\
\mathrm{PM}_{2.5} \\
\left(\mu \mathrm{g} \mathrm{m}^{-3}\right)\end{array}$ & References \\
\hline Indoors ${ }^{\mathrm{b}}$ & $\mathrm{NA}^{\mathrm{c}}$ & $6 \pm 3$ & $39 \pm 20$ & $\begin{array}{l}\text { Li and Lin } \\
\text { (2003) }\end{array}$ \\
\hline \multicolumn{5}{|l|}{ Northern Taiwan } \\
\hline $\begin{array}{l}\text { Taipei, } \\
\text { underpass }^{\mathrm{d}}(n=5)\end{array}$ & $117 \pm 14$ & NA & $223 \pm 31$ & $\begin{array}{l}\text { Hung and } \\
\text { Wang } \\
\text { (2001) }\end{array}$ \\
\hline Taipei, urban ${ }^{\mathrm{e}}$ & NA & $9 \pm 2$ & $51 \pm 8$ & $\begin{array}{l}\mathrm{Li} \text { and Lin } \\
\text { (2002) }\end{array}$ \\
\hline \multicolumn{5}{|l|}{ Central Taiwan } \\
\hline $\begin{array}{l}\text { Taichung, } \\
\text { roadside }{ }^{\mathrm{d}}(n=9)\end{array}$ & $42 \pm 25$ & NA & $93 \pm 53$ & $\begin{array}{l}\text { Chang et al. } \\
\text { (2001) }\end{array}$ \\
\hline Taichung, urban ${ }^{\mathrm{e}}$ & $6 \pm 3$ & NA & $65 \pm 40$ & Chio (2005) \\
\hline \multicolumn{5}{|l|}{ Southern Taiwan } \\
\hline $\begin{array}{l}\text { Tainan, } \\
\operatorname{urban}^{\mathrm{e}}(n=59)\end{array}$ & NA & NA & $73 \pm 38$ & $\begin{array}{l}\text { Tsai and } \\
\text { Kuo (2005) }\end{array}$ \\
\hline $\begin{array}{l}\text { Kaohsiung, } \\
\operatorname{urban}^{\mathrm{e}}(n=20)\end{array}$ & NA & $10 \pm 4$ & NA & $\begin{array}{l}\text { Tsai et al. } \\
(2005)\end{array}$ \\
\hline Pingtung, roadside ${ }^{\mathrm{d}}$ & $31 \pm 19$ & NA & $140 \pm 41$ & $\begin{array}{l}\text { Lin et al. } \\
(2005)\end{array}$ \\
\hline $\begin{array}{l}\text { Pingtung, urban }{ }^{\mathrm{e}} \\
(n=21)\end{array}$ & NA & NA & $72 \pm 21$ & $\begin{array}{l}\text { Chen et al. } \\
\text { (2004) }\end{array}$ \\
\hline
\end{tabular}

${ }^{\mathrm{a}}$ Estimated $\mathrm{PM}_{0.18}$ concentrations are calculated by Max $\left(0.20 \times \mathrm{PM}_{1}, 0.15 \times \mathrm{PM}_{2.5}\right)$. This empirical equation is adopted from Chio et al. (2006).

${ }^{\mathrm{b}}$ Assumed that $\mathrm{PM}_{2.5}$ and $\mathrm{PM}_{0.18}$ measured indoors are representative of northern, central and southern Taiwan.

c NA: Data not available.

${ }^{d}$ PM measured at underpass and roadside is classified as in-traffic.

${ }^{\mathrm{e}} \mathrm{PM}$ measured in urban area is classified as outdoor.

of ROS consequent to inhalation of PM particularly that derived from combustion of fossil fuel was a likely cause of inflammation in the lung, while Hiura et al. (1999) have demonstrated that DEP-induced ROS can cause cell apoptosis. Finkel and Holbrook (2000) indicated that the balance between ROS production and antioxidant defenses determines the degree of oxidative stress (OS), and Kelly (2000) reported that OS is instrumental in the aetiology of numerous human diseases (e.g. coronary heart disease, myocardial ischemia, cystic fibrosis, adult respiratory disease syndrome, and asthma).

Gilmour et al. (2004) studied that the inflammatory and cytokine responses in plasma caused from the PMinduced ROS determining by Trolox equivalent antioxidant capacity (TEAC) assay. Chen et al. (2006) described a positive correlation between $\mathrm{PM}_{10}$ concentrations and the cumene-hydroperoxide equivalent concentration (CEC) in that the CEC represented the ROS level generated by cumene-hydroperoxide. Furthermore, Kuo et al. (1998) indicated that ROS caused the inhibition of gap junctional intercellular communication (GJIC) and intercellular glutathione (GSH) content, the major small molecular weight cellular and epithelial surface thiol antioxidant. Nel et al. (2006) posited that the ratio of GSH to its oxidized form, glutathione disulphide (GSSG), should be a suitable indicator to describe several tiers of OS level including normal response, antioxidant defense, inflammation, and cytotoxicity. In support, Yeh et al. (2005) observed that there were significant decreases in the levels of GSH, GSSG, and the ratio of GSH/GSSG in the blood of patients with breast cancer compared to those of a control group $(p<0.05)$, yet a non-significant decrease in the vitamin E level. Chang et al. (2005) also reported an increase in OS and ROS production and a decrease in GSH/GSSG ratio in BEAS-2B cells on exposure to cooking oil fumes. OS is evident in the cell in increased conversion of GSH to GSSG (Donaldson et al., 1998), and hence the GSH/GSSG ratio in the cell is a good indicator of the level of OS (Halliwell and Gutteridge, 1999; Schafer and Buettner, 2001). Li et al. (2002) employed this ratio in determining level of injury suffered by human macrophage (THP-1) and human bronchial epithelial (BEAS-2B) cells exposed to DEP.

DEP cannot be measured directly in the atmospheric environment because it is only one of many sources in ambient aerosol. A receptor model, however, allows the source apportionment of an ambient mixture of pollutants to the contributing pollution sources, and can be used in this instance to quantify the DEP concentration. Receptor models include the Bayesian model (Chan et al., 1996), the chemical mass balance (CMB) model (Watson et al., 1991), the positive matrix factorization (PMF) model (Paatero and Tapper, 1994; Paatero, 1997), and other statistical methods (Henry, 1991). In this research we also employed the human respiratory tract (HRT) model (ICRP, 1994) to estimate the internal DEP concentration or dose in human lung regions. Chen et al. (2005) reported that the haematological markers of increased cardiovascular disease risks were associated with long driving time ( $10 \mathrm{~h} /$ day and 26 days/month) for taxi drivers in Taipei. In their opinion described in the discussion section, they indicated that the drivers exposed to vehicle exhaust may be one of the reasons to support their results. Therefore, we considered that the driver setting was the noteworthy subgroup in Taiwan for our study, and chose the homeworker and student settings as compared subgroups (lesser exposure time in traffic activity) in the same time.

We reanalyzed the published data for indoor, outdoor and in-traffic particulate matter from different regions in Taiwan, incorporated the HRT model into dose- 
Table 2

The estimated volume of air breathed for driver, homeworker, and student at indoor, outdoor, and in-traffic activities

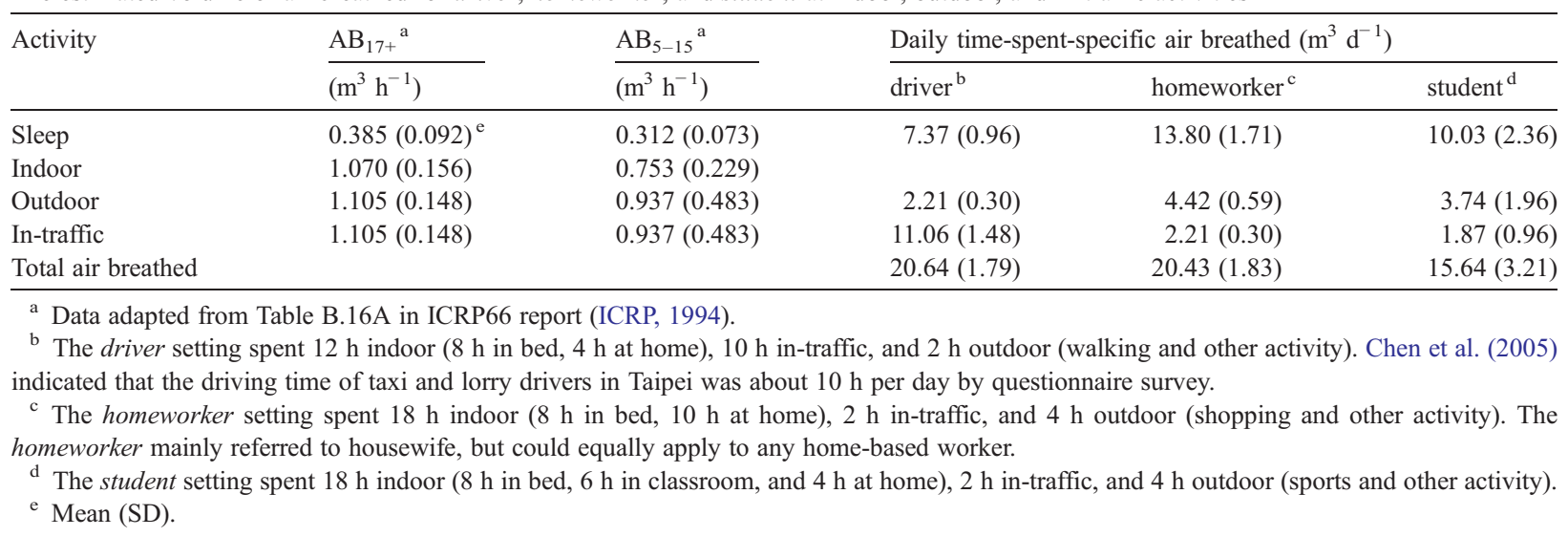

response profiles to assess the risk estimates, and performed a Monte Carlo (MC) simulation to evaluate the uncertainties resulting from the assessments of exposure and dose-response in the risk estimates. The purposes of this study were (1) to quantify the effective or internal DEP exposure in actual atmospheric environments and (2) to assess probabilistically the DEP-induced OS risk in selected occupational settings.

\section{Materials and methods}

Our probabilistic risk assessment (PRA) framework is divided into four parts (Fig. 1) and will be described in the subsequent sections.

\subsection{Problem formulation: data reanalysis}

Studied designs of our study include the northern, central, and southern Taiwan regions, three selected settings (driver, homeworker and student) and three activities (indoor, outdoor and in-traffic) are taken into account for exposure assessment (Fig. 1a). The excellent available published data for $\mathrm{PM}_{2.5}$ and $\mathrm{PM}_{0.18}$ in Taiwan (Chang et al., 2001; Hung and Wang, 2001; Li and Lin, 2002, 2003; Chen et al., 2004; Chio, 2005; Lin et al., 2005; Tsai and Kuo, 2005; Tsai et al., 2005) was divided into several subgroups representing (1) different regions in Taiwan (northern, central, and southern) and (2) different activities (indoor, outdoor and in-traffic) within those regions (see Table 1 for complete data sources).

\subsection{Exposure assessment}

In order to quantify the DEP dose, it is necessary to determine the percentage of DEP in vehicle-emitted particulate and the vehicle contribution to the ambient $\mathrm{PM}_{2.5}$ prior to estimating $\mathrm{DEP}_{2.5}$ concentration from atmospheric environment (Fig. 1b). Chio (2005) estimated the percentage of vehicle contribution to ambient $\mathrm{PM}_{2.5}$ as $34.1-84.8 \%$ using a CMB model, while the percentage of DEP in vehicle-emitted particulate has been estimated at between 26 and $69 \%$, based on calculations using Bayesian (Chio, 2005), CMB (Gertler, 2005) and PMF (Zhao and Hopke, 2004) models. Furthermore, Lin et al. (2005) found that the major fraction in DEP was ultrafine, and ranged from 41.5 to $45.9 \%$ of the total. We are able to estimate the contribution of $\mathrm{DEP}_{0.18}$ to $\mathrm{PM}_{0.18}$ based on that finding. DEP contributory ratios were estimated in this study using the source apportionment technologies (Bayesian, CMB, and PMF), and we employed Crystal Ball ${ }^{\circledR}$ (Version 2000.2, Decisioneering, Inc., Denver, Colorado, USA) to perform the MC simulation, with simulation frequencies of 10,000 iterations to ensure the variability of results. A lognormal probability distribution was used to define the possible variables.

We apply the HRT model (ICRP, 1994) to estimate the internal exposure doses in different lung regions (Fig. 1b). The model divides the respiratory tract into five major compartments: (i) the nasal passage $\left(\mathrm{ET}_{1}\right)$, comprising the anterior nose and posterior nasal passages; (ii) the pharynx $\left(\mathrm{ET}_{2}\right)$, comprising larynx and mouth; (iii) the bronchial region (BB), comprising the airway from the trachea, main bronchi, and intrapulmonary bronchi; (iv) the bronchiolar region (bb), comprising bronchioles and terminal bronchioles; and (v) the alveolar-interstitial region (AI), comprising the airway from respiratory bronchioli through alveolar sacs (ICRP, 1994; Liao et al., 2003, 2006). Based on the principle of mass balance, the HRT model, varying with 


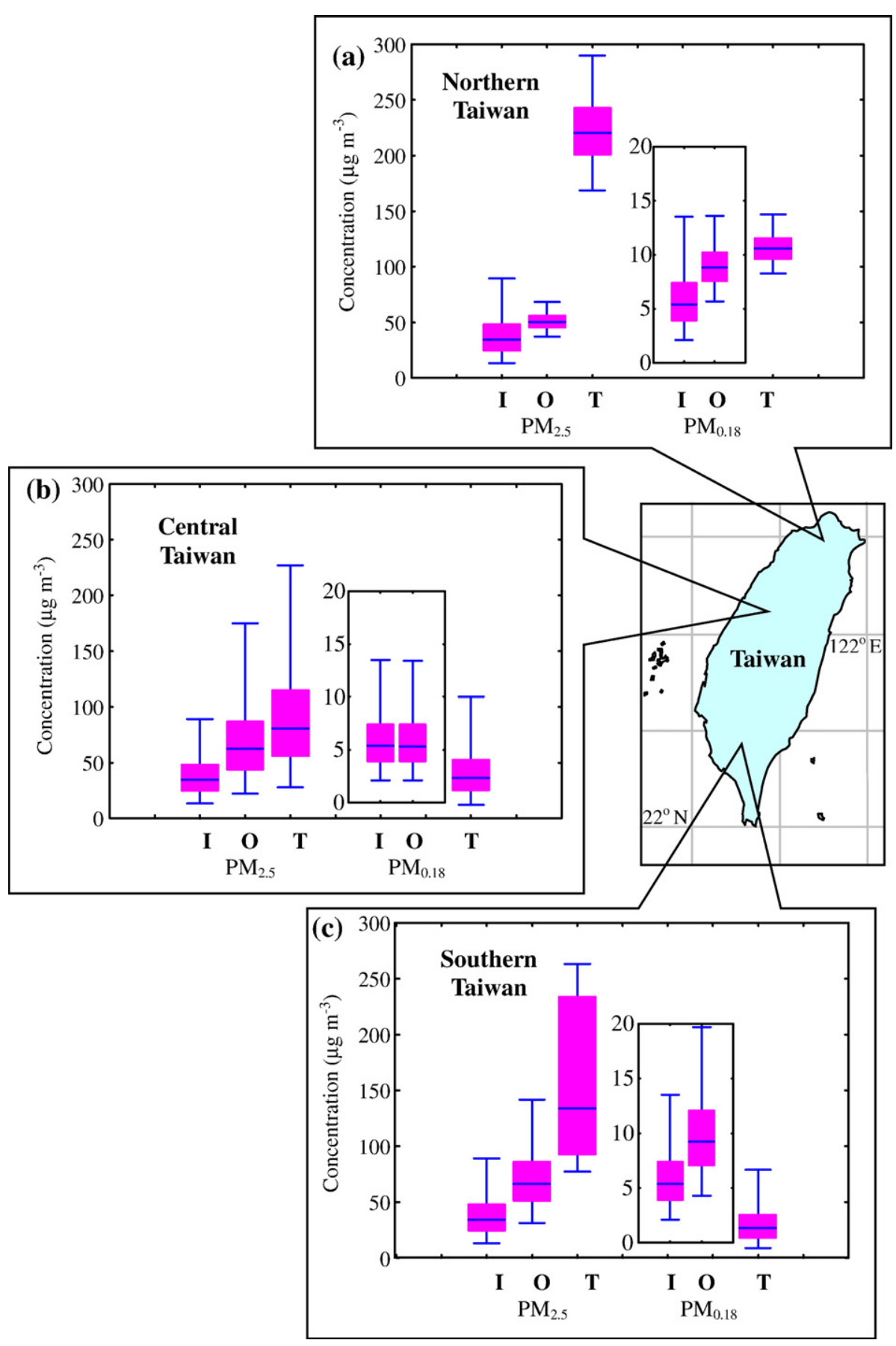

Fig. 2. Distribution of $\mathrm{PM}_{2.5}$ and $\mathrm{PM}_{0.18}$ mass concentration estimated during indoor (I), outdoor (O), and in-traffic (T) activities in (a) northern, (b) central, and (c) southern Taiwan using 10,000 Monte Carlo simulations.

particle size ranges of $\mathrm{PM}_{2.5}$ and $\mathrm{PM}_{0.18}$ and equilibrium time to each regional compartment and represented by a linear dynamic equation (Liao et al., 2003, 2006), was used to estimate DEP concentration in lung regions. We solved the linear dynamic equation to obtain the mass lung/indoor (L/I) ratio based on an equilibrium state in each compartment, and the specific fractional deposition $\left(d_{\mathrm{F}}\right)$ for $\mathrm{PM}_{2.5}$ and $\mathrm{PM}_{0.18}$ in each compartment was then estimated, with a focus on the lung tissue of the lower respiratory tract $(\mathrm{BB}, \mathrm{bb}$ and $\mathrm{AI})$. 

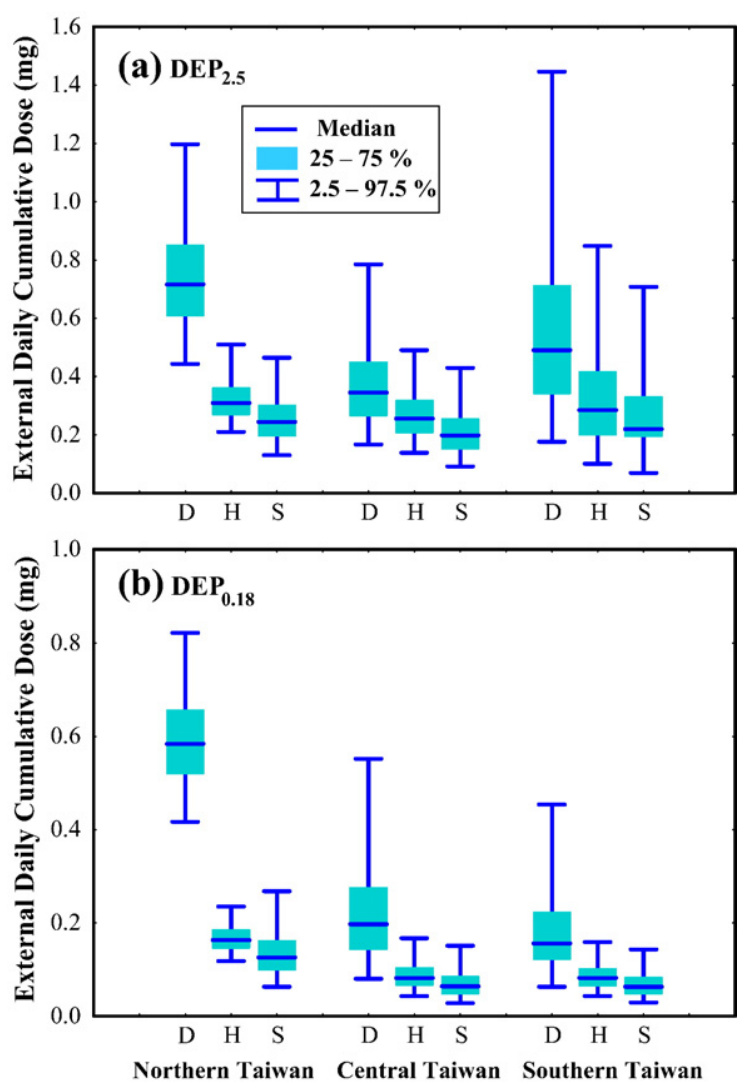

Fig. 3. Daily cumulative dose exposure to (a) $\mathrm{DEP}_{2.5}$ and (b) $\mathrm{DEP}_{0.18}$ for driver (D), homeworker (H), and student (S) in different Taiwan regions.

We converted the data into a daily cumulative dose, the product of exposure to DEP concentration $\left(C_{\mathrm{DEP}}\right)$, volume of air breathed $(A B)$, and time spent $(T S)$ of each activity.
We assume that the driver setting will spent half time indoors in one day, and while the homeworker and student settings spent $75 \%$ of the time indoors (see Table 2 for complete activity breakdown). The activity profiles placed driver indoors $50 \%$ of the time and allowance was made for an interchange ratio ( $I R$, ratio of alveolar ventilation to blood flow rate: $230 / 290=0.7931)$ between air breathed and blood interfaces (Ramsey and Anderson, 1984) and for the clearance effect in the lung tissue while DEP deposited on $\mathrm{BB}, \mathrm{bb}$ and $\mathrm{AI}$ regions. A 2-year duration was adopted as an appropriate exposure time based on the half-time of particulate removed from AI to $\mathrm{ET}_{2}$ (ICRP, 1994). The total cumulative dose in lung tissue was calculated as the sum of the doses in individual compartments multiplied by the exposure time $(T)$. The following equation could describe clearly the algorithm of the total internal cumulative DEP dose $(D)$ :

$D=C_{\mathrm{DEP}} \times A B \times T S \times d_{\mathrm{F}} \times I R \times T$.

\subsection{Effect assessment}

We constructed a dose-response profile by fitting an empirical three parameters Hill equation model to the published data ( $\mathrm{Li}$ et al., 2002) on DEP dose-GSH/ GSSG ratio in human macrophages (THP-1) and human brochial epithial cells (BEAS-2B) (Fig. 1c):

$R=1-\frac{R(D)}{R(0)}=\frac{R_{\max } \times D^{n}}{K_{0.5}^{n} \times D^{n}}$

where $R$ is the measured response (\%), $R(D)$ is the GSH/GSSG ratio response for a specific DEP dose, $R$

Table 3

Fractional deposition in respiratory tract regions for $\mathrm{DEP}_{0.18}$ and $\mathrm{DEP}_{2.5}$

\begin{tabular}{|c|c|c|c|c|c|c|c|c|}
\hline & $\lambda_{\mathrm{d}_{i}\left(\mathrm{~s}^{-1}\right)}^{\mathrm{a}}$ & $\lambda_{\mathrm{s}_{i}\left(\mathrm{~s}^{-1}\right)}^{\mathrm{a}}$ & $\lambda_{\mathrm{im}_{i}}^{\mathrm{a}}\left(\mathrm{s}^{-1}\right)$ & $\varepsilon_{i}^{\mathrm{a}}(-)$ & $Q^{\mathrm{b}}\left(\mathrm{m}^{3} \mathrm{~d}^{-1}\right)$ & $V_{i}^{\mathrm{a}}\left(\mathrm{cm}^{3}\right)$ & $\mathrm{L} / \mathrm{I}$ ratio $^{\mathrm{c}}(-)$ & $d_{\mathrm{F}_{i}}^{\mathrm{d}}(-)$ \\
\hline \multicolumn{9}{|c|}{$\mathrm{DEP}_{0.18}$} \\
\hline $\mathrm{BB}$ & $1.40 \mathrm{E}-4$ & $1.80 \mathrm{E}-4$ & $4.90 \mathrm{E}-3$ & $4.21 \mathrm{E}-9$ & $2.04 \mathrm{E}+1$ & $9.46 \mathrm{E}+1$ & $5.98 \mathrm{E}-1$ & $1.25 \mathrm{E}-3$ \\
\hline $\mathrm{bb}$ & $1.68 \mathrm{E}-3$ & $7.42 \mathrm{E}-3$ & $5.89 \mathrm{E}-2$ & $3.61 \mathrm{E}-6$ & $2.04 \mathrm{E}+1$ & $5.10 \mathrm{E}+2$ & $3.98 \mathrm{E}-1$ & $5.85 \mathrm{E}-2$ \\
\hline \multirow[t]{2}{*}{ AI } & $6.34 \mathrm{E}-3$ & $1.48 \mathrm{E}-2$ & $8.24 \mathrm{E}-2$ & $2.43 \mathrm{E}-4$ & $2.04 \mathrm{E}+1$ & $1.58 \mathrm{E}+3$ & $2.40 \mathrm{E}-1$ & $1.66 \mathrm{E}-1$ \\
\hline & & & & & & & Total $d_{\mathrm{F}_{i}}=$ & $2.26 \mathrm{E}-1$ \\
\hline \multicolumn{9}{|c|}{$\mathrm{DEP}_{2.5}$} \\
\hline $\mathrm{BB}$ & $7.99 \mathrm{E}-5$ & $1.04 \mathrm{E}-2$ & $2.45 \mathrm{E}-2$ & $4.22 \mathrm{E}-9$ & $2.04 \mathrm{E}+1$ & $9.46 \mathrm{E}+1$ & $4.53 \mathrm{E}-1$ & $6.35 \mathrm{E}-3$ \\
\hline $\mathrm{bb}$ & $9.59 \mathrm{E}-4$ & $1.24 \mathrm{E}-1$ & $2.94 \mathrm{E}-1$ & $3.62 \mathrm{E}-6$ & $2.04 \mathrm{E}+1$ & $5.10 \mathrm{E}+2$ & $1.86 \mathrm{E}-1$ & $1.68 \mathrm{E}-1$ \\
\hline \multirow[t]{2}{*}{$\mathrm{AI}$} & $2.01 \mathrm{E}-3$ & $2.49 \mathrm{E}-1$ & $3.53 \mathrm{E}-1$ & $2.45 \mathrm{E}-4$ & $2.04 \mathrm{E}+1$ & $1.58 \mathrm{E}+3$ & $3.70 \mathrm{E}-2$ & $1.50 \mathrm{E}-1$ \\
\hline & & & & & & & Total $d_{\mathrm{F}_{i}}=$ & $3.24 \mathrm{E}-1$ \\
\hline
\end{tabular}

adapted from Liao et al. (2006) in that $\lambda_{\mathrm{d}_{i}}, \lambda_{\mathrm{s}_{i}}$, and $\lambda_{\mathrm{im}_{i}}$ represent the turbulent diffusive deposition rate, gravitational settling rate, and inertial impaction rate, respectively, and $\varepsilon_{i}$ is the interception deposition efficiency in compartment $i$.

${ }^{\mathrm{b}} Q$ is the daily volume of air breathed $(A B)$.

${ }^{\mathrm{C}} \mathrm{L} / \mathrm{I}$ ratio $\left(=C_{\mathrm{i}} / C_{\mathrm{I}}\right)$ is estimated from HRT model.

${ }^{\mathrm{d}} d_{\mathrm{F}_{i}}=\frac{C_{i}}{C_{I}}\left[\left(\lambda_{\mathrm{d}_{i}}+\lambda_{\mathrm{s}_{i}}+\lambda_{\mathrm{im}_{i}}\right) \frac{V_{i}}{Q}+\varepsilon_{i}\right]$ (Liao et al., 2006). 

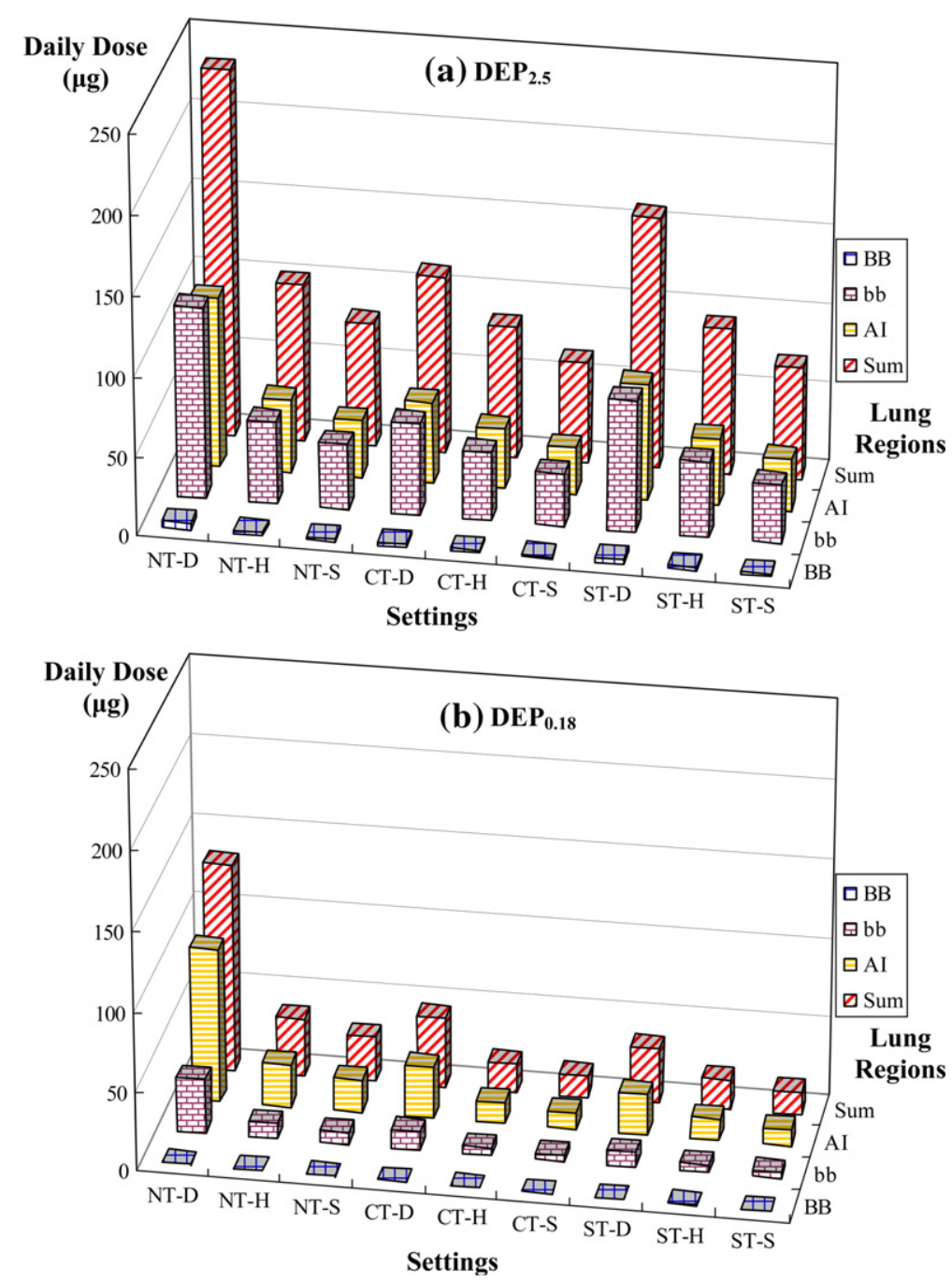

Fig. 4. Daily (a) $\mathrm{DEP}_{2.5}$ and (b) $\mathrm{DEP}_{0.18}$ dose ( $\mu \mathrm{g}$ ) distributed in different lung regions at steady-state condition (BB: the bronchial region, bb: the bronchiolar region, $\mathrm{AI}$ : alveolar-interstitial region, $\mathrm{Sum}$ : $\mathrm{BB}+\mathrm{bb}+\mathrm{AI})$.

(0) is the GSH/GSSG ratio response when the dose equal to zero, $K_{0.5}$ is the DEP cumulative dose yielding half the maximal response of $R_{\max }(\%), D$ is the DEP cumulative dose in the lung (mg), and the exponent $n$ is a fitted average value, the Hill coefficient, a measure of cooperativity. A value of $n>1$ indicates positive cooperativity. We used TableCurve 2D (Version 5, AISN Software Inc., Mapleton, OR, USA) to optimize the dose-response profile with significance at $p<0.05$. We converted the DEP concentration in $\mu \mathrm{g} \mathrm{ml}^{-1}$ to the cumulative dose in mg under the assumptions that DEP is carried in the blood and that the total volume of blood is nearly $5.5 \mathrm{~L}$ (Fox, 2004).

We treated the $K_{0.5}$ value in Eq. (2) probabilistically. The cumulative distribution function (CDF) of the predicted response function for a given DEP dose is expressed as a conditional CDF:

$P(R \mid D)=\Phi\left(\frac{R_{\max } \times D^{n}}{K_{0.5}^{n} \times D^{n}}\right)$

where $\Phi(\mathbf{O})$ is the cumulative standard normal distribution.

Li et al. (2002) also reported that the induction of cellular toxicity in THP-1 cells occurred at a DEP dose $>25 \mu \mathrm{g} \mathrm{ml}^{-1}$, whereas the onset of cell death in BEAS-2B cells was nearly linear at DEP doses $\geqq 10 \mu \mathrm{g} \mathrm{ml}^{-1}$. We considered that these two concentration-based doses as the critical doses for their responses, and the corresponding values can be found in the model for DEP dose- 
response profiles. Nel et al. (2006) constructed a hierarchical OS model to describe the relationships among GSH/GSSG ratio (as the level of OS), genetic responses and obvious outcomes through response and signaling pathways. We employed these concepts to predict the DEP-induced GSH/GSSG ratio decreasing situations when people exposed to different scenarios.

\subsection{Risk characterization}

Risk characterization provides an estimate of risk for the specific subpopulation under study (Fig. 1d). The risk at a specific DEP dose of OS can be calculated as the proportion of human lung expected to be subjected to that DEP dose multiplied by the conditional probability of OS. A joint probability function (JPF) or exceedence profile describes the probability of exceeding the cumulative dose associated with the related response and can be expressed mathematically as

$P(R)=P(R \mid D) \times P(D)$,

where $P(R)$ is the probabilistic risk for a certain cumulative dose $D, P(R \mid D)$ is the CDF of having DEP cumulative dose $D$ in human lung tissue, and $P(D)$ is the probability of DEP cumulative dose $D$ in human lung tissue.

\section{Results and discussion}

\subsection{Exposure analysis}

\subsubsection{Data treatment}

From published data (Table 1) we produced estimations of the $\mathrm{PM}_{2.5}$ and $\mathrm{PM}_{0.18}$ mass concentration in indoor, outdoor and in-traffic activities in northern, central, and southern Taiwan (Fig. 2). Mass concentrations in traffic were generally higher than in indoor and outdoor activities. Uncertainties associated with intraffic $\mathrm{PM}_{2.5}$ levels in central and southern Taiwan (28.1-227 and 77.3-234 $\mu \mathrm{g} \mathrm{m}^{-3}$, respectively) were higher than in northern Taiwan (168.8-243.6 $\mu \mathrm{g} \mathrm{m}^{-3}$ ). While $\mathrm{PM}_{2.5}$ concentration in indoor and outdoor activities tended to be lower in northern than that in central and southern Taiwan, no similar phenomenon was apparent for $\mathrm{PM}_{0.18}$ (Fig. 2).

\subsubsection{DEP concentration conversion}

We incorporated the ratio of the vehicle contribution to the ambient $\mathrm{PM}_{2.5}$ and the ratio of $\mathrm{DEP}_{2.5}$ to the total vehicle exhaust particle to estimate the $\mathrm{DEP}_{2.5}$ concentration. The former is best fitted as a lognormal distribu- tion $(\mathrm{GM}=0.507$ and $\mathrm{GSD}=1.4)$ and the latter estimated as a lognormal distribution $(\mathrm{GM}=50.7$ and $\mathrm{GSD}=1.4)$. The transformation factor of $\mathrm{PM}_{0.18}$ to $\mathrm{DEP}_{0.18}$ was then obtained $(\mathrm{GM}=0.436$ and $\mathrm{GSD}=1.1)$. The $\mathrm{DEP}_{2.5}$ and $\mathrm{DEP}_{0.18}$ daily cumulative doses were calculated using the average $\mathrm{DEP}_{2.5}$ and $\mathrm{DEP}_{0.18}$ concentrations multiplied by the specific daily air breathed $(\mathrm{AB})$ rates, based on ICRP66 (ICRP, 1994) and shown in Table 2 as 20.64, 20.43 , and $15.64 \mathrm{~m}^{3} \mathrm{~d}^{-1}$ for driver, homeworker, and student, respectively. The median daily cumulative dose of external $\mathrm{DEP}_{2.5}$ with $95 \%$ confidence intervals (CIs) for driver was 0.716 (0.443-1.197), 0.345 (0.167$0.785)$, and $0.491(0.176-1.446) \mathrm{mg}$ in northern, central, and southern Taiwan, respectively. It was lower in all three regions for homeworker and student, and ranged from 0.198 to $0.309 \mathrm{mg}$. The median daily cumulative dose data for $\mathrm{DEP}_{0.18}$ show even more forcefully that driver in northern Taiwan is the highest dose category, experiencing a dose of $0.584(0.417-0.822) \mathrm{mg}$ of $\mathrm{DEP}_{0.18}$ compared with a range of 0.083 to $0.197 \mathrm{mg}$ for other settings (Fig. 3).

\subsubsection{Human lung deposition}

By applying the HRT model to estimate the internal DEP dose, the results indicate that the fractional deposition value for $\mathrm{DEP}_{2.5}$ in bb (0.168) region is higher than that in $\mathrm{BB}(0.006)$ and $\mathrm{AI}(0.150)$ regions, whereas it was highest for $\mathrm{DEP}_{0.18}$ in $\mathrm{AI}(0.166)$ region. The total fractional deposition in $\mathrm{BB}, \mathrm{bb}$, and $\mathrm{AI}$ regions for $\mathrm{DEP}_{2.5}$ and $\mathrm{DEP}_{0.18}$ was 0.324 and 0.226 , respectively (Table 3 ). We combined the external DEP doses from three different regions for three settings (Fig. 3) and the size-specific fractional deposition values (Table 3), we could calculate the medians and uncertainties of internal DEP doses for nine selected subgroups. We performed the median internal $\mathrm{DEP}_{2.5}$ and $\mathrm{DEP}_{0.18}$ in Fig. 4. We assumed that the DEP dose deposited on low respiratory tract $(\mathrm{BB}, \mathrm{bb}$, and $\mathrm{AI}$ regions) could cause the macrophages to swallow those particles. In light of this concept, the driver in northern Taiwan had the highest internal $\mathrm{DEP}_{2.5}$ and $\mathrm{DEP}_{0.18}$ dose (232.2 and $132.1 \mu \mathrm{g}$ ) compared with those in southern (159.2 and $14.2 \mu \mathrm{g})$ and central (111.9 and $44.5 \mu \mathrm{g}$ ) Taiwan (Fig. 4a, b).

The median $\mathrm{DEP}_{2.5}$ daily cumulative dose for driver, homeworker, and student in northern Taiwan was 0.716 , 0.309 , and $0.244 \mathrm{mg}$, respectively (Fig. 3a), leading to an estimated median $\mathrm{DEP}_{2.5}$ daily cumulative dose in $\mathrm{BB}$, $\mathrm{bb}$, and AI regions for those settings of 232.2, 100.2, and $79.1 \mu \mathrm{g}$ (Fig. 4a). We applied the ratio of the vehicle contribution to the ambient $\mathrm{PM}(\mathrm{GM}=0.507, \mathrm{GSD}=1.4)$ and the ratio of DEP to the vehicle exhaust particle $(\mathrm{GM}=0.507, \mathrm{GSD}=1.4)$ in northern Taiwan to estimate 

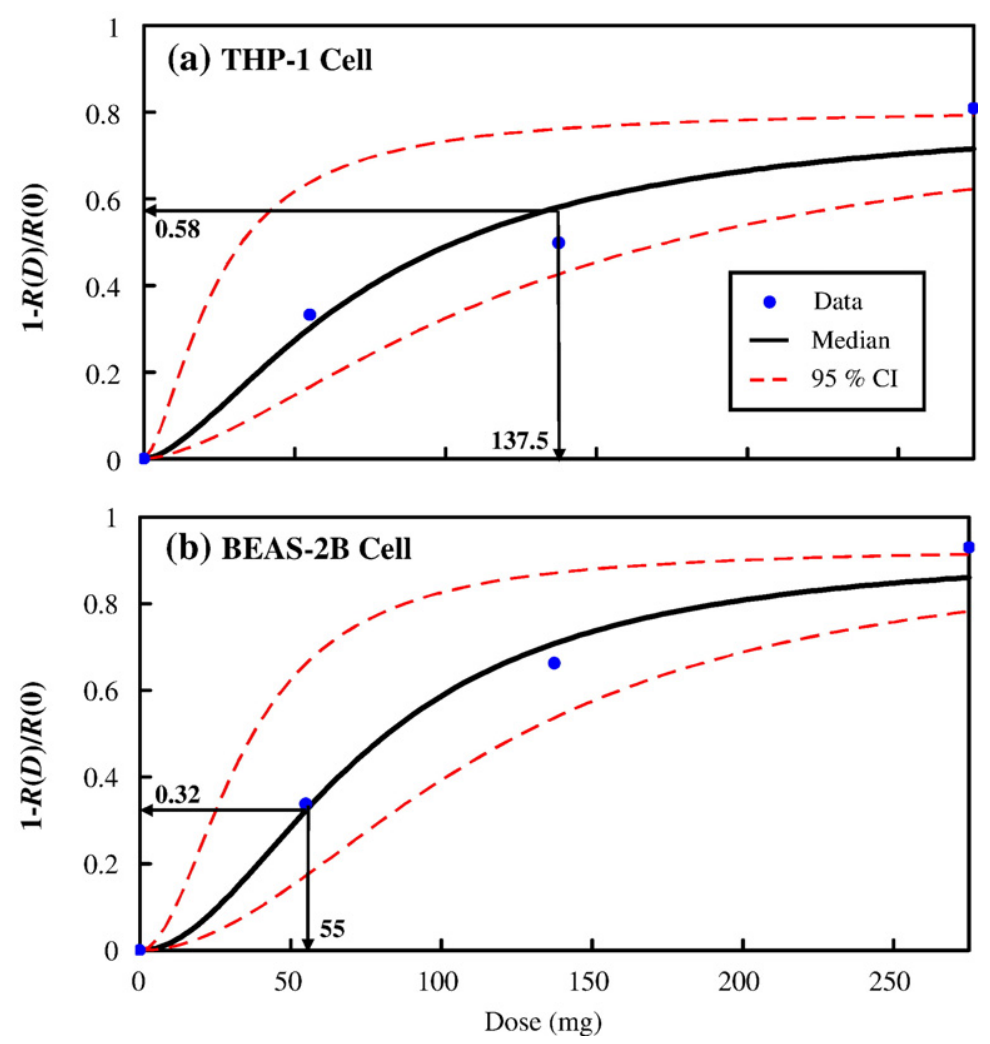

Fig. 5. Dose-response profiles optimally fitted by a three parameters Hill equation model with $95 \%$ confidence interval in (a) THP-1 and (b) BEAS2B cells for DEP cumulative dose.

the $\mathrm{PM}_{2.5}$ dose in deep lung tissue, producing a median daily $\mathrm{PM}_{2.5}$ dose in lung tissue for driver, homeworker, and student of 631, 272, and $215 \mu \mathrm{g}$, respectively. The median daily $\mathrm{PM}_{2.5}$ dose for driver (can be seen as male adult), homeworker (can be seen as female adult), and student (can be seen as youth) estimated by the PEARLS (Particulate Exposure from Ambient to Region Lung by Subgroup) model is 24.6, 20.8, and $22.4 \mu \mathrm{g}$ based on an average $\mathrm{PM}_{2.5}$ concentration of $15 \mu \mathrm{g} \mathrm{m}^{-3}$ (Gower and McColl, 2005).

In our study the estimations are based on $\mathrm{PM}_{2.5}$ concentration of 34.7-220.9 $\mu \mathrm{g} \mathrm{m}^{-3}$ (Fig. 2a). The conversion to a concentration of $15 \mu \mathrm{g} \mathrm{m}^{-3}$ produces a median daily $\mathrm{PM}_{2.5}$ dose for driver, homeworker and student of $184.6,89.5$, and $82.7 \mu \mathrm{g}$, respectively, resulting in our estimated doses in lung tissue nearly 2.5-3.4 times higher than the values estimated via PEARLS model.

We also apply the multiple-path particle dosimetry (MPPD) model version 2 developed by CIIT Centers for Health Research (2006) to validate our $d_{\mathrm{F}}$ values by using HRT model. The $d_{\mathrm{F}}$ values of $\mathrm{PM}_{0.18}$ and $\mathrm{PM}_{2.5}$ by using MPPD model are 0.204 and 0.277 , respectively, whereas the values conducted from HRT model are 0.226 and
0.324 , indicating that the $d_{\mathrm{F}}$ values of $\mathrm{PM}_{0.18}$ and $\mathrm{PM}_{2.5}$ from MPPD and HRT models are insignificantly different.

\subsection{Effect analysis}

\subsubsection{Dose-response profiles construction}

The dose-response profiles in THP-1 and BEAS-2B cells indicate that the $95 \%$ CIs for $K_{0.5}$ are estimated by the corresponding value of maximal residual multiplied by $t$ statistical value $\left(t_{(0.025,3)}=3.182\right)$ (Fig. 5$)$. The maximum response $R_{\max }$ in THP- 1 and BEAS-2B cells was estimated at 0.8088 and 0.9297 , respectively. The Hill coefficient ( $n$ ) in THP-1 cells was estimated at 1.59, and that in BEAS-2B at 1.96 , with a $r^{2}>0.95$. The specific DEP cumulative dose yielding half of maximal response $K_{0.5}$ for THP-1 and BEAS-2B cells with 95\% CIs was estimated at $76.29(24.01-128.57) \mathrm{mg}$ and 76.03 (34.77-117.29) $\mathrm{mg}$, respectively.

\subsubsection{Hierarchical OS model and critical levels}

The hierarchical OS model could be used to describe the relationships among GSH/GSSG ratio (i.e. level of OS), cell response pathways, signaling pathways, genetic 

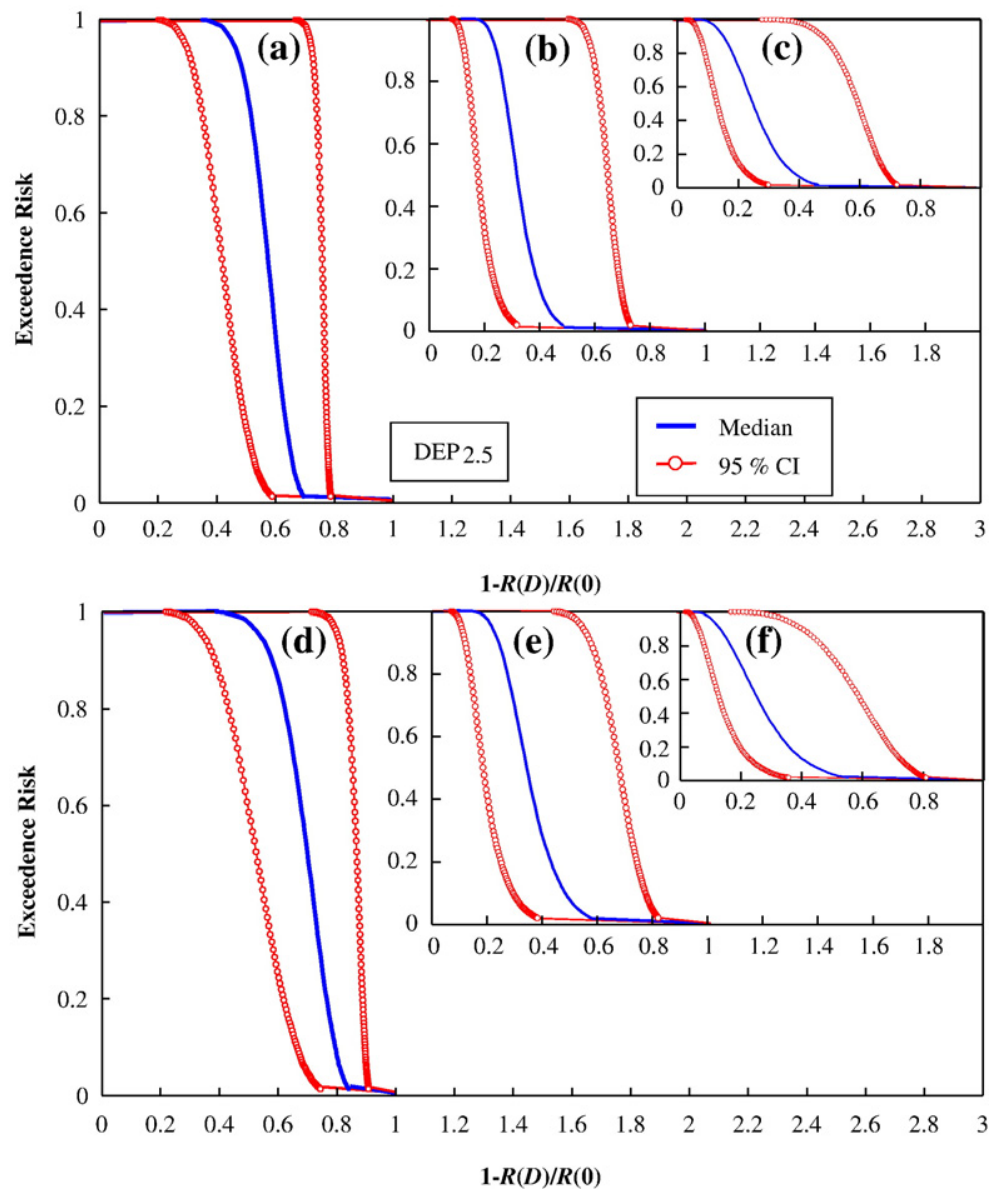

Fig. 6. Estimate exceedence risk curves with $95 \%$ confidence interval in THP-1 and BEAS-2B cells, respectively, for (a, d) driver, (b, e) homeworker, and (c, f) student exposed to $\mathrm{DEP}_{2.5}$ for a 2-year duration in northern Taiwan.

responses and significant outcomes (Halliwell and Gutteridge, 1999). The antioxidant response was found for cellular redox homeostasis in tier 1 (lower amount of OS). The inflammation and cytotoxcicty responses were found in tier 2 (medium amount of OS) and tier 3 (high amount of OS) (Halliwell and Gutteridge, 1999; Nel et al., 2006). Li et al. (2002) observed that the cytotoxicity response in THP-1 cells and cell death in BEAS-2B cells occurred at a DEP dose equal to or greater than 25 and $10 \mu \mathrm{g} \mathrm{ml}^{-1}$, respectively. These critical points for DEP dose were estimated to be $137.5 \mathrm{mg}(R=0.58)$ and $55.0 \mathrm{mg}(R=0.32)$ for THP-1 and BEAS-2B cells, respectively (Fig. 5).

\subsection{Risk analysis}

\subsubsection{Regional assessment}

For $\mathrm{DEP}_{2.5}$, the median response in THP-1 cells for driver in northern Taiwan was, at 0.57 , near the critical 0.58 (Fig. 6a) and hence this setting is at risk of $\mathrm{DEP}_{2.5^{-}}$ induced oxidative stress in these cells. The upper band of the $95 \%$ CI for homeworker and student also encompasses the critical 0.58 level (Fig. 6b, c) and hence these settings also are at potential risk of $\mathrm{DEP}_{2.5}$-induced oxidative stress. The median response in BEAS-2B cells was above critical (0.32) for driver in all three regions of Taiwan (Fig. 6d-f), sometimes substantially, again identifying risk of $\mathrm{DEP}_{2.5}$-induced $\mathrm{OS}$ for the driver settings and furthermore that risk is greater than for THP1 cells. For $\mathrm{DEP}_{0.18}$, median responses in THP-1 cells indicated insignificant risk of OS for driver in northern Taiwan (Fig. 7a) and no risk for homeworker and student (Fig. 7b, c), whereas those in BEAS-2B cells indicated a significant risk of OS for driver (Fig. 7d), and a potential risk for homeworker and student, the upper bands of the $95 \%$ CI of which again encompass the critical level (Fig. 7e, f).

The results show that there is a potential risk of OS from exposure to $\mathrm{DEP}_{2.5}$, via exceedence of the critical levels $(R>0.58$ in THP- 1 and $R>0.32$ in BEAS-2B), in 

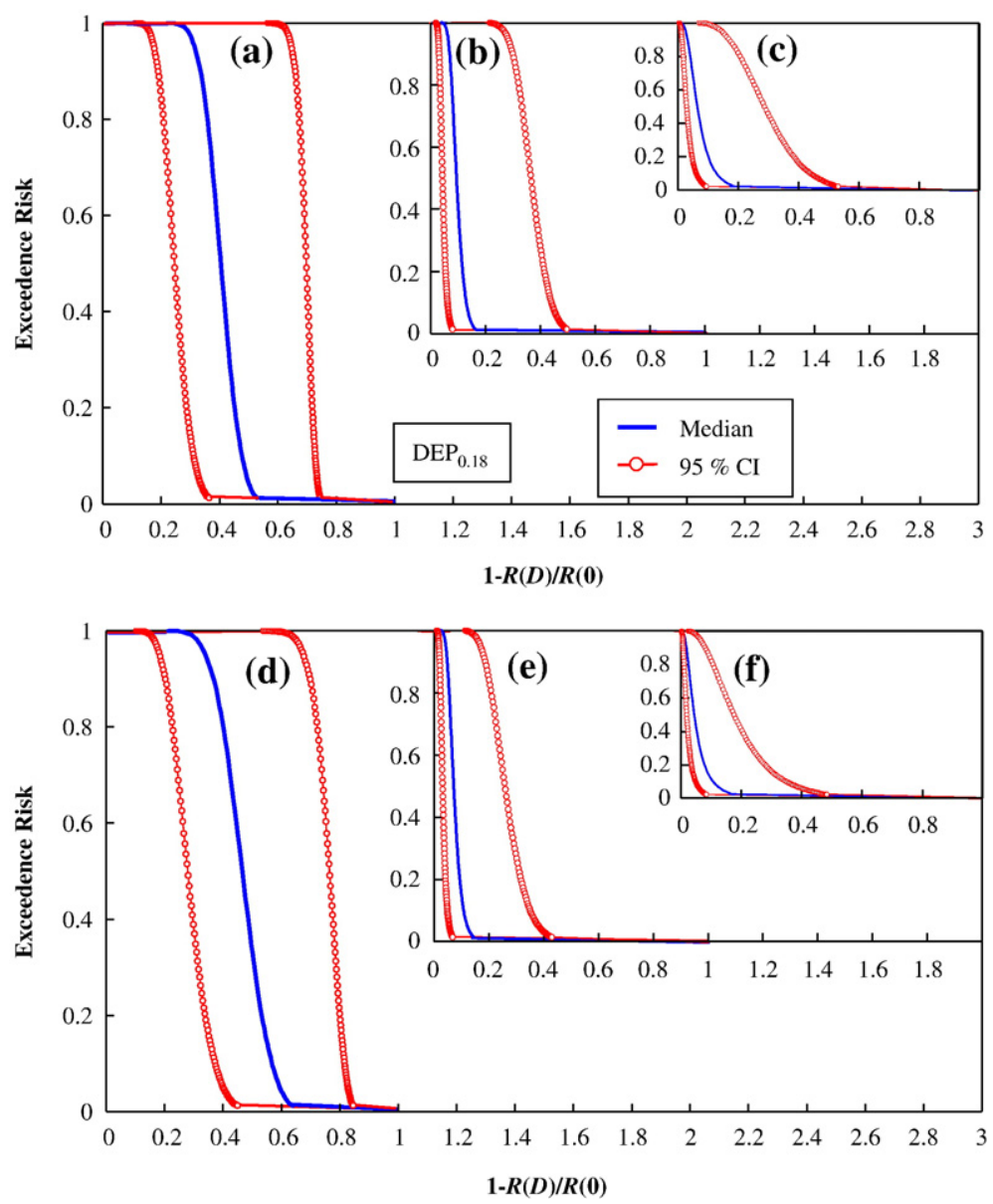

Fig. 7. Estimate exceedence risk curves with $95 \%$ confidence interval in THP-1 and BEAS-2B cells, respectively, for (a, d) driver, (b, e) homeworker, and $(\mathrm{c}, \mathrm{f})$ student exposed to $\mathrm{DEP}_{0.18}$ for a 2-year duration in northern Taiwan.

all settings investigated, indicated by the $95 \%$ CIs (Table 4), whereas the risk from exposure to $\mathrm{DEP}_{0.18}$ is largely limited to driver in northern Taiwan. The potential risk to driver from $\mathrm{DEP}_{2.5}$ in northern Taiwan is approximately 2-3 times that to homeworker or student, while the potential risk from $\mathrm{DEP}_{0.18}$ is $4-11$ times higher (Fig. 3). Comparing the potential risk in THP-1 and BEAS-2B cells for the same occupational settings in different Taiwan regions indicates that the OS risk from $\mathrm{DEP}_{2.5}$ and $\mathrm{DEP}_{0.18}$ is in the order northern Taiwan $>$ southern Taiwan $\approx$ central Taiwan (Table 4 ).

\subsubsection{Population level assessment}

The complete process of risk assessment for an integrated data conducted from Taiwan is shown in Fig. 8. Fig. 8a, indicating that the model input data (PM) which result from $\mathrm{MC}$ simulation and all of them are considered as lognormal distributions (LN(GM, GSD)). The $\mathrm{PM}_{2.5}$ values are $\mathrm{LN}(34.7,1.6), \operatorname{LN}(59.4,1.5)$ and
$\mathrm{LN}(133.5,1.7)$ in indoor, outdoor, and in-traffic settings, respectively, whereas the $\mathrm{PM}_{0.18}$ values are $\mathrm{LN}(5.37$, 1.6), $\operatorname{LN}(7.63,1.6)$ and $\operatorname{LN}(48.8,2.2)$ in these three environmental settings. Fig. $8 \mathrm{~b}$ shows the external DEP concentrations for driver (D), homeworker $(\mathrm{H})$ and student (S) settings. The daily median $\mathrm{DEP}_{2.5}$ and $\mathrm{DEP}_{0.18}$ concentrations with $95 \% \mathrm{CI}$ for driver setting are 0.584 (0.219-1.298) and $0.26(0.07-1.18) \mathrm{mg}$, respectively.

The external DEP in the other two settings (homeworker and student) are insignificantly different each other and less than that in driver setting. Fig. 8c presents the $\mathrm{DEP}_{2.5}$ and $\mathrm{DEP}_{0.18}$ daily doses deposited on the lung tissue, the influential $\mathrm{DEP}_{2.5}$ (include $\mathrm{BB}$, $\mathrm{bb}$, and AI regions) are 157.6, 92.4, and $84.3 \mu \mathrm{g} \mathrm{m}^{-3}$ for driver, homeworker and student settings, respectively, whereas the $\mathrm{DEP}_{0.18}$ doses are only 58.8, 22.6, and $20.4 \mu \mathrm{g} \mathrm{m}^{-3}$. Results show that the daily doses for driver setting are significant than the other two settings. 
Table 4

Cumulative dose-response with $95 \%$ confidence intervals (CIs) in THP-1 and BEAS-2B cells for driver, homeworker, and student exposed to $\mathrm{DEP}_{2.5}$ and $\mathrm{DEP}_{0.18}$ for 2-year duration

\begin{tabular}{|c|c|c|c|c|}
\hline & \multicolumn{2}{|c|}{ THP-1 cell } & \multicolumn{2}{|c|}{ BEAS-2B cell } \\
\hline & Median & $(95 \% \mathrm{CI})$ & Median & $(95 \% \mathrm{CI})$ \\
\hline \multicolumn{5}{|l|}{$\mathrm{DEP}_{2.5}$} \\
\hline \multicolumn{5}{|l|}{ Northern Taiwan } \\
\hline Driver & 0.57 & $(0.42-0.76)$ & 0.70 & $(0.53-0.87)$ \\
\hline Homeworker & 0.32 & $(0.18-0.65)$ & 0.34 & $(0.19-0.68)$ \\
\hline Student & 0.25 & $(0.13-0.60)$ & 0.25 & $(0.13-0.59)$ \\
\hline \multicolumn{5}{|l|}{ Central Taiwan } \\
\hline Driver & 0.35 & $(0.20-0.67)$ & 0.39 & $(0.22-0.72)$ \\
\hline Homeworker & 0.26 & $(0.14-0.61)$ & 0.27 & $(0.14-0.61)$ \\
\hline Student & 0.20 & $(0.10-0.54)$ & 0.18 & $(0.09-0.49)$ \\
\hline \multicolumn{5}{|l|}{ Southern Taiwan } \\
\hline Driver & 0.46 & $(0.30-0.72)$ & 0.55 & $(0.36-0.81)$ \\
\hline Homeworker & 0.29 & $(0.16-0.63)$ & 0.31 & $(0.16-0.65)$ \\
\hline Student & 0.22 & $(0.11-0.57)$ & 0.22 & $(0.11-0.54)$ \\
\hline \multicolumn{5}{|l|}{$\mathrm{DEP}_{0.18}$} \\
\hline \multicolumn{5}{|l|}{ Northern Taiwan } \\
\hline Driver & 0.40 & $(0.25-0.70)$ & 0.47 & $(0.28-0.77)$ \\
\hline Homeworker & 0.09 & $(0.04-0.37)$ & 0.07 & $(0.03-0.26)$ \\
\hline Student & 0.07 & $(0.03-0.29)$ & 0.04 & $(0.02-0.18)$ \\
\hline \multicolumn{5}{|l|}{ Central Taiwan } \\
\hline Driver & 0.12 & $(0.06-0.43)$ & 0.10 & $(0.05-0.33)$ \\
\hline Homeworker & 0.03 & $(0.02-0.18)$ & 0.02 & $(0.01-0.08)$ \\
\hline Student & 0.04 & $(0.01-0.13)$ & 0.01 & $(0.01-0.05)$ \\
\hline \multicolumn{5}{|l|}{ Southern Taiwan } \\
\hline Driver & 0.09 & $(0.04-0.35)$ & 0.07 & $(0.03-0.24)$ \\
\hline Homeworker & 0.03 & $(0.02-0.18)$ & 0.02 & $(0.01-0.08)$ \\
\hline Student & 0.02 & $(0.01-0.12)$ & 0.01 & $(0.01-0.05)$ \\
\hline
\end{tabular}

Fig. $8 \mathrm{~d}$ presents the risk for driver setting expose to ambient population level in overall Taiwan region. Based on the assessment for 2-year duration, the median cumulative dose-responses with $95 \% \mathrm{CI}$ in THP-1 and BEAS-2B cells for driver exposed to $\mathrm{DEP}_{2.5}$ are 0.27 (0.14-0.61) and $0.28(0.14-0.61)$, respectively, whereas the corresponding values expose to $\mathrm{DEP}_{0.18}$ only fall on $0.18(0.09-0.51)$ and $0.16(0.08-0.46)$.

\subsection{Improvement strategy}

Our results show that driver in northern Taiwan is at the highest risk from $\mathrm{DEP}_{2.5}$ exposure. Based on sensitivity analysis, the time-spent-specific air breathed rate and $\mathrm{PM}_{2.5}$ or $\mathrm{PM}_{0.18}$ concentrations for in-traffic activity are the most two factors affecting the daily cumulative dose of $\mathrm{DEP}_{2.5}$ or $\mathrm{DEP}_{0.18}$. The daily cumulative dose of $\mathrm{DEP}_{2.5}$ is correlated with time spent in the higher $\mathrm{PM}_{2.5}$ concentrations of the in-traffic activity, as shown in sensitivity analysis. Results also show that the internal $\mathrm{DEP}_{0.18}$ daily exposure (median $=0.132$ with $95 \% \mathrm{CI}=0.094-0.186 \mathrm{mg}$ ) is the largest fraction of $\mathrm{DEP}_{2.5}$ daily exposure (median $=0.232$ with $95 \%$ $\mathrm{CI}=0.144-0.388 \mathrm{mg}$ ) for driver in northern Taiwan. Therefore, the potential risk from DEP-induced ROS could clearly be reduced by reducing the time spent in the in-traffic activity (Table 2).

The second strategy is to reduce the PM level from roadside or underpass (i.e. in-traffic activity), yet this is an expensive and time-consuming task. We must provide a lot of methods to decrease the pollutants emitted from vehicle exhaust, including emission standard legislation (Maga, 1982), improvement of traffic types (ex. changes in traffic volumes, speed, vehicle age distributions, dieselvehicle fractions and congestion levels) (McCarthy et al., 2006), and improvement of fuel use (Sharp, 1998; Swanson et al., 2007). Many researches have shown a less decrease in PM emissions with biodiesel, whereas the other pollutants (NOx and OC) may increase (Sharp, 1998; Swanson et al., 2007).

ITRI (2007) suggested that the biodiesel can be mixed with fossil diesel or directly used by diesel engines with no engine adjustment necessary. According to ITRI's evaluation, there are $30-50 \%$ and $5-15 \%$ of PM reduction for pure biodiesel (B100) and the blend of 20\% biodiesel with $80 \%$ fossil diesel (B20), respectively (ITRI, 2007). Although this improvement of fuel use can reduce the PM level from in-traffic activity, the emerging pollutants emitted from biodiesel-burned vehicles should be studied more detail. The relationships between biodiesel exhaust emissions and human health are not clear so far (Swanson et al., 2007). Based on the knowledge of biodiesel technology, we cannot assess the human health induced by biodiesel through our proposed model. The major reason is that the selected dose-response profiles or significant endpoints may be changed.

\subsection{Model improvement}

In our proposed model, DEP (and/or PM) dose is association with OS response, whereas the particle size, surface area, and chemical composition impact on the mode and type of lung injury sustained from PM (Donaldson et al., 1998). Smaller particulates have higher mobility, are more easily inhaled, and may cause a larger fraction deposition in human lung and penetrate the alveolar epithelial barrier into the blood/lymphatic system (Biswas and Wu, 2005). Nemmar et al. (2003) showed that while fine particulate inhalation can induce lung inflammation, ultrafine can additionally induce thrombosis. The exact surface area for measured DEP is very difficult to obtain and, moreover, only PM mass 


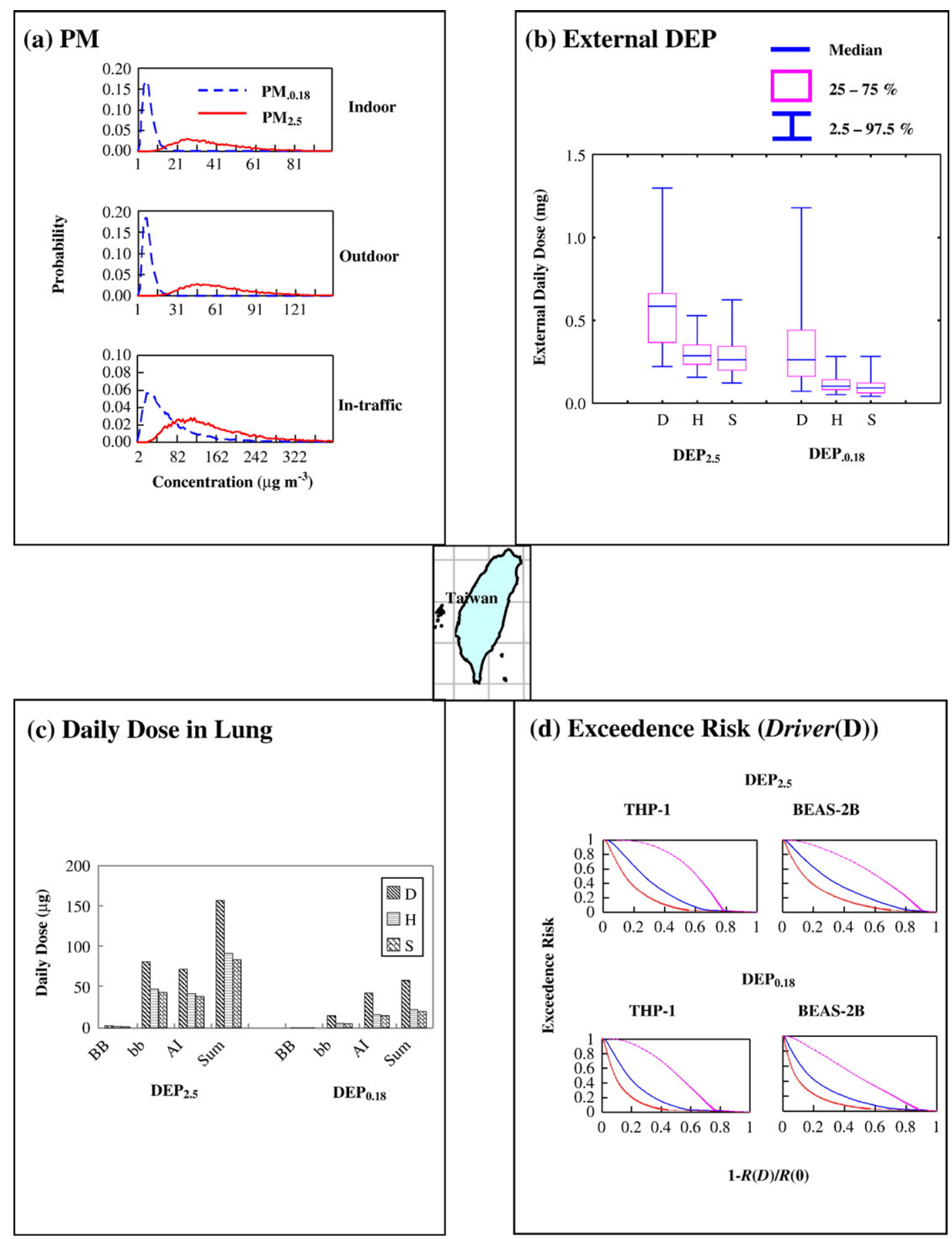

Fig. 8. Model inputs and outputs based on an integrated Taiwan setting. (a) PM, (b) External DEP, (c) Daily Dose in Lung, and (d) Exceedence risk.

concentrations were known in the original data sources for this study.

Furthermore, no dose-response profiles with GSH/ GSSG indicator based on surface area and number concentration were found. For these reasons, we focused on the mass concentration of the DEP dose in this study, yet maybe more suitable effects/endpoints correlated to surface area-based or number concentration-based of DEP or their compositions can be found in near future. Currently, our proposed model should be used cautiously, 
whereas they can be enhanced more reliable and valuable based on overcoming more knowledge gapes.

The GSH/GSSG ratio was able to describe the OS state for exposure to DEP, detailed indexes of lung toxicity including inflammation, cytotoxicity, parenchyma change, and general toxicity potencies should be introduced in the future (McDonald et al., 2004). To date, many researches have indicated that the DEP-induced health effect from in vitro and in vivo studies, including lung tumor rate (Mauderly et al., 1987; Heinrich et al., 1995), inflammatory and genotoxic effects (Dybdahl et al., 2004). Our proposed endpoint (GSH/GSSG ratio in human cells line) is selected to prevent the predicament of species differences. Our explanations are (i) we should take into account the modifying factors when the effects conducted from the rodent studies are selected and (ii) we are intended to assess the preliminary effect on human lung epithelial cells and macrophages expose to ambient particles (PM and/or DEP). Our models have combine the appropriate dose-response relationships and critical concentrations from $\mathrm{Li}$ et al. (2002) with the hierarchical oxidative stress (OS) model from previous studies (Halliwell and Gutteridge, 1999; Nel et al., 2006) to predict the OS potential risk exposing to atmospheric particles. Although many in vivo studies provide useful information in rat model, there are inadequate dose-response profiles for employing in our study.

\section{Conclusions}

In conclusion, we have quantified the effective DEP exposure in atmospheric environment and assessed probabilistically the human OS risk from DEP-induced ROS in selected occupational settings. We employed an HRT model to successfully estimate the $\mathrm{DEP}_{2.5}$ and $\mathrm{DEP}_{0.18}$ cumulative doses deposited in lung compartments and applied DEP dose-response profiles based on mass to evaluate simultaneously the OS risk for human macrophage cells (THP-1) and human bronchial epithelial cells (BEAS-2B). The government or decision makers are encouraged to use these results to initiate and set an environmental quality standard or emission standard for diesel exhaust particulate. In future work, we may incorporate the surface area and/or number concentration-based DEP dose-response profiles to precisely describe the risk potential induced by DEP.

\section{References}

Biswas P, Wu CY. Nanoparticles and the environment. J Air Waste Manage Assoc 2005;55:708-46.
Chan CC, Nien CK, Hwang JS. Receptor modeling of VOCs, CO, NOx, and THC in Taipei. Atmos Environ 1996;30:25-33.

Chang KF, Fang GC, Lu CS, Bai HL. Particle size distribution and anion content at traffic site in Sha-Lu, Taiwan. Chemosphere 2001;45:791-9.

Chang LW, Lo WZ, Lin P. Trans, trans-2,4-decadienal, a product found in cooking oil fumes, induces cell proliferation and cytokine production due to reactive oxygen species in human bronchial epithelial cells. Toxicol Sci 2005;87:337-43.

Chen SJ, Hsieh LT, Kao MJ, Lin WY, Huang KL, Lin CC. Characteristics of particles sampled in southern Taiwan during the Asia dust storm periods in 2000 and 2001. Atmos Environ 2004;38:5925-34.

Chen JC, Chen YJ, Chang WP, Christiani DC. Long driving time is associated with haematological markers of increase cardiovascular risk in taxi divers. Occup Environ Med 2005;62:890-4.

Chen SJ, Cheng SY, Shue MF, Huang KL, Tsai PJ, Lin CC. The cytotoxicities induced by $\mathrm{PM}_{10}$ and particle-bound water-soluble species. Sci Total Environ 2006;354:20-7.

Chio CP. 2005. Chemical compositions and source contributions of $\mathrm{PM}_{2.5}$ and $\mathrm{PM}_{2.5-10}$ for urban and coastal areas in central Taiwan. PhD Thesis, National Chung Hsing University, Taichung, Taiwan, ROC.

Chio CP, Cheng MT, Wang CF. Source apportionment to $\mathrm{PM}_{10}$ in different air quality conditions for Taichung urban and coastal areas, Taiwan. Atmos Environ 2004;38:6893-905.

Chio CP, Cheng MT, Chen SC, Liao CM. Ultrafine particle (UFP) mass and number concentrations estimated from $\mathrm{PM}_{2.5}$ mass concentration. Proceeding of 13th International Conference on Aerosol Science and Technology, 29-30 September. Tainan, Taiwan: Chinese Association for Aerosol Research in Taiwan (CARRT); 2006. (Po-22-135).

Cho AK, Sioutas C, Miguel AH, Kumagai Y, Schmitz DA, Singh M, et al. Redox activity of airborne particulate matter at different sites in the Los Angels Basin. Environ Res 2005;99:40-7.

CIIT Centers For Health Research. Multiple-path particle dosimetry (MPPD) model version 2 software; 2006 (Available: http://www. ciit.org [accessed 9 March 2006]).

Donaldson K, Li XY, MacNee W. Ultrafine (nanometre) particle mediated lung injury. J Aerosol Sci 1998;29:553-60.

Dybdahl M, Risom L, Bornholdt, Autrup H, Loft S, Wallin H. Inflammatory and genotoxic effects of diesel particles in vitro and in vivo. Mutat Res 2004;562:119-31.

Finkel T, Holbrook NJ. Oxidants, oxidative stress and the biology of ageing. Nature 2000;408:239-46.

Fox SI. Human physiology. 8th ed. Taipei: McGraw-Hill; 2004.

Gertler AW. Diesel vs. gasoline emissions: does PM from diesel or gasoline vehicles dominate in the US? Atmos Environ 2005;39:2349-55.

Gilmour PS, Ziesenis A, Morrison ER, Vickers MA, Drost EM, Ford I, et al. Pulmonary and systemic effects of short-term inhalation exposure to ultrafine carbon black particles. Toxicol Appl Pharmacol 2004;195:35-44.

Gower SK, McColl S. Development of the PEARLS model (particulate exposure from ambient to regional lung by subgroup) and use of Monte Carlo simulation to predict internal exposure to $\mathrm{PM}_{2.5}$ in Toronto. Risk Anal 2005;25:301-15.

Halliwell B, Gutteridge JMC. Free radicals in biology and medicine. 3rd ed. New York: Oxford University Press; 1999.

Heinrich U, Fuhst R, Rittinghausen S, Creutzberg O, Bellmann B, Koch W, et al. Chronic inhation exposure of wistar rats and 2 different strains of mice to diesel-engine exhaust, carbon-black, and titanium-dioxide. Inhal Toxicol 1995;7:533-56. 
Henry RC. Multivariate receptor models. In: Hopke PK, editor. Receptor modeling for air quality management. New York: Elsevier; 1991. p. 117-47.

Hiura TS, Kaszubowski MP, Li N, Nel AE. Chemicals in diesel exhaust particles generate reactive oxygen radicals and apoptosis in macrophages. J Immunol 1999;163:5582-91.

Hung HF, Wang CS. Experimental determination of reactive oxygen species in Taipei aerosols. J Aerosol Sci 2001;32:1201-11.

ICRP. Human respiratory tract model for radiological protection, a report of a task group of the international commission on radiological protection. ICRP Publication. New York: Elsevier; 1994.

ITRI, 2007. Available: http://www.itri.org.tw/index.jsp [accessed 31 May 2007].

Iwai K, Adachi S, Takshashi M, Möller L, Udagawa T, Mizuno S, et al. Early oxidative DNA damages and late development of lung cancer in diesel exhaust-exposed rats. Environ Res 2000;84:255-64 (Section A).

Kao MC, Wang CS. Reactive oxygen species in incense smoke. Aerosol Air Qual Res 2002;2:61-9.

Kelly FJ. Free radical involvement in cardiovascular and respiratory diseases. In: Rhodes CJ, editor. Toxicology of the human environment - the critical role of free radicals. London: Taylor and Francis; 2000. p. 363-70.

Knaapen AM, Borm PJA, Albrecht C, Schins RPF. Inhaled particles and lung cancer. Part A: mechanisms. Int J Cancer 2004;109:799-809.

Kuo ML, Jee SH, Chou MH, Ueng TH. Involvement of oxidative stress in motorcycle exhaust particle-induced DNA damage and inhibition of intercellular communication. Mutat Res 1998;413:143-50.

Li CS, Lin $\mathrm{CH}$. $\mathrm{PM}_{1} / \mathrm{PM}_{2.5} / \mathrm{PM}_{10}$ characteristics in the urban atmosphere of Taipei. Aerosol Sci Tech 2002;36:469-73.

Li CS, Lin CH. Carbon profile of residential indoor $\mathrm{PM}_{1}$ and $\mathrm{PM}_{2.5}$ in the subtropical region. Atmos Environ 2003;37:881-8.

Li N, Wang M, Oberley TD, Sempf JM, Nel AE. Comparison of the pro-oxidative and proinflammatory effects of organic diesel exhausts particle chemicals in bronchial epithelial cells and macrophages. J Immunol 2002;169:4531-41.

Liao CM, Chen JW, Huang SJ. Size-dependent $\mathrm{PM}_{10}$ indoor/outdoor/ personal relationships for a wind-induced naturally ventilated airspace. Atmos Environ 2003;37:3065-75.

Liao CM, Chen SC, Chen JW, Liang HM. Contributions of Chinesestyle cooking and incense burning to person exposure and residential PM concentrations in Taiwan region. Sci Total Environ 2006;358:72-84.

Lin CC, Chen SJ, Huang KL, Hwang WI, Chang-Chien GP, Lin WY. Characteristics of metals in nano/ultrafine/fine/coarse particles collected beside a heavily trafficked road. Environ Sci Technol 2005;39:8113-22.

Maga JA. Emission standards for mobile sources. In: Stern AC, editor. Air pollution, Third Edition, Volume V: Air quality management. Taiwan: University Book Publishing Company; 1982. p. 506-67.

Mauderly JL, Jones RK, Griffith WC, Henderson RF, McClellan RO. Diesel exhaust is a pulmonary carcinogen in rats exposed chronically by inhalation. Fundam Appl Toxicol 1987;9:208-21.

McCarthy MC, Eisinger DS, Hafner HR, Chinkin LR, Roberts PT, Black KN, et al. Particulate matter: a strategic vision for transportation -related research. Environ Sci Technol 2006;40:5593-9.
McDonald JD, Eide I, Seagrave J, Zielinska B, Whitney K, Lawson DR, et al. Relationship between composition and toxicity of motor vehicle emission samples. Environ Health Perspect 2004;112:1527-38.

Nel AE. Air pollution-related illness: effects of particles. Science 2005;308:804-6.

Nel AE, Xia T, Mädler L, Li N. Toxic potential of materials at the nanolevel. Science 2006;311:622-7.

Nemmar A, Hoylaerts MF, Hoet PHM, Vermylen Z, Nemery B. Size effect of intratracheally instilled particles on pulmonary inflammation and vascular thrombosis. Toxicol Appl Pharmacol 2003;186:38-45.

Paatero P. Least squares formulation of robust nonnegative factor analysis. Chem Intell Lab Syst 1997;37:23-35.

Paatero P, Tapper U. Positive matrix factorization: a nonnegative factor model with optimal utilization of error estimates of data values. Environmetrics 1994;5:111-26.

Pelicano H, Carney D, Huang P. ROS stress in cancer cells and therapeutic implications. Drug Resist Updat 2004;7:97-110.

Ramsey JC, Andersen M. A physiologically based description of the inhalation pharmacokinetics of strene in rats and humans. Toxicol Appl Pharmacol 1984;73:159-75.

Reliene R, Hlavacova A, Mahadevan B, Baird WM, Schiestl RH. Diesel exhaust particles cause increased levels of DNA deletions after transplacental exposure in mice. Mutat Res 2005;570:245-52.

Schafer FQ, Buettner GR. Redox environment of the cell as viewed through the redox state of the glutathione disulfide/glutathione couple. Free Radic Biol Med 2001;30:1191-212.

Sharp C. Characterization of biodiesel exhaust emissions for EPA 211 (b). Report, San Antonio, TX:Southwest Research Institute; 1998.

Swanson KJ, Madden MC, Ghio AJ. Biodiesel exhaust: the need for health effects research. Environ Health Perspect 2007;115:496-9.

Tovalin H, Valverde M, Morandi MT, Blanco S, Whitehead L, Rojas E. DNA damage in outdoor workers occupationally exposed to environmental air pollutants. Occup Environ Med 2006;63:230-6.

Tsai YI, Kuo SC. $\mathrm{PM}_{2.5}$ aerosol water content and chemical composition in a metropolitan and a coastal area in southern Taiwan. Atmos Environ 2005;39:4827-39.

Tsai JH, Chang KL, Lin JJ, Lin YH, Chiang HL. Mass-size distributions of particulate sulfate, nitrate, and ammonium in a particulate matter nonattainment region in southern Taiwan. J Air Waste Manage Assoc 2005;55:502-9.

USEPA. Health assessment document for diesel engine exhaust. National Center for Environmental Assessment, USEPA: Washington, DC; 2002.

Watson JG, Chow JC, Pace TG. Chemical mass balance. In: Hopke PK, editor. Receptor modeling for air quality management. New York: Elsevier; 1991. p. 83-116.

Yeh CC, Hou MF, Tsai SM, Lin SK, Hsiao JK, Huang JC, et al. Superoxide anion redical, lipid peroxides and antioxidant status in the blood of patients with breast cancer. Clin Chim Acta 2005;361:104-11.

Zhao W, Hopke PK. Source apportionment for ambient particles in the San Gorgonio wilderness. Atmos Environ 2004;38:5901-10. 